\title{
PENGARUH PEMBERITAAN MEDIA MASSA TERHADAP PERSEPSI MASYARAKAT TENTANG SUSU KENTAL MANIS
}

\author{
Ika Chandra W. ${ }^{1}$, Rini Sudarmanti ${ }^{2}$ \\ 1ika.chandra.w@gmail.com, ${ }^{2}$ rini.sudarmanti@paramadina.ac.id \\ 1,2Universitas Paramadina
}

Naskah diterima tanggal 23-11-2020, direvisi tanggal 28-01-2021, disetujui tanggal 28-02-2021

\begin{abstract}
Abstrak. Susu kental manis merupakan produk yang familiar di tengah masyarakat di Indonesia. Selama puluhan tahun, masyarakat merasa nyaman mengonsumsi produk ini hingga muncul berbagai pemberitaan mengenai susu kental manis. Penelitian ini bertujuan untuk mengetahui pengaruh pemberitaan media massa terhadap persepsi ibu tentang susu kental manis serta seberapa besar pengaruh pemberitaan tersebut terhadap persepsi. Penelitian menggunakan pendekatan kuantitatif dengan metode survei eksplanatif dengan populasi ibu dari siswa Yayasan Al-Hikmah, Tangerang Selatan. Data diambil dengan menggunakan kuisioner pada sebanyak 116 responden. Dari berbagai sumber pemberitaan mengenai susu kental manis, responden memiliki kesimpulan tersendiri mengenai inti pemberitaan. Mayoritas responden yaitu sebesar 78,4 persen menjawab poin dari berbagai pemberitaan tersebut adalah kandungan gula dalam susu kental manis. Hasil analisis dalam penelitian ini menunjukkan bahwa pemberitaan media massa berpengaruh positif dan siginifikan terhadap persepsi para ibu siswa sekolah Yayasan Al-Hikmah mengenai susu kental manis. Hubungan antara pemberitaan media massa dan persepsi ibu tentang susu kental manis juga dinyatakan sebagai hubungan yang kuat. Perhitungan nilai koefisien determinasi atau $\mathrm{R}^{2}$ menghasilkan angka sebesar 0,381 . Artinya pemberitaan media massa memberikan pengaruh sebesar 38,1 persen terhadap persepsi. Sedangkan sisanya yaitu sebesar 61,9 persen merupakan kontribusi variabel lain selain pemberitaan media massa.
\end{abstract}

Kata kunci: susu kental manis, komunikasi massa, media massa, pemberitaan, persepsi.

\begin{abstract}
Sweetened condensed milk is a familiar product in Indonesian society. For decades, people have felt comfortable consuming this product until various reports have emerged about sweetened condensed milk. This study aims to determine the effect of mass media coverage on mothers' perceptions of sweetened condensed milk and how much it influenced the perception. The study used a quantitative approach with an explanative survey method with a population of mothers from students of the Al-Hikmah Foundation, South Tangerang. Data were collected using a questionnaire on as many as 116 respondents. From various sources of news about sweetened condensed milk, respondents have their own conclusions about the core of the news. The majority of respondents, namely 78.4 percent, answered that the points from the various reports were the sugar content in sweetened condensed milk. The results of the analysis in this study indicate that mass media coverage has a positive and significant effect on the perceptions of the mothers of Al-Hikmah Foundation school students regarding sweetened condensed milk. The relationship between mass media coverage and mothers' perceptions of sweetened condensed milk is also stated as a strong relationship. The calculation of the coefficient of determination or $R^{2}$ yields a number of 0.381 . This means that mass media coverage has an effect of 38.1 percent on perceptions. While the rest, which is 61.9 percent, is the contribution of other variables besides mass media coverage.
\end{abstract}

Keywords: sweetened condensed milk, mass communication, mass media, news, perception. 


\section{PENDAHULUAN}

Komunikasi massa, menurut Littlejohn \& Foss (2009) merupakan proses organisasi media menciptakan dan menyebarkan pesan-pesan pada masyarakat luas dan proses pesan tersebut dicari, digunakan, dipahami, dan dipengaruhi audiens. Semakin modern kehidupan, komunikasi massa juga semakin dibutuhkan. Alasannya adalah, "dalam masyarakat sederhana, kesepakatan bisa dicapai dengan pembicaraan langsung, sedangkan masyarakat industri yang kompleks harus mengandalkan media massa (Rivers et al., 2008, p.34). Di masa kini media massa banyak memainkan peran dalam menyebarkan berbagai bentuk pesan baik melalui media cetak, televisi, radio, ataupun internet. Media massa menjadi bagian yang tidak terpisahkan dari kehidupan manusia.

Di Indonesia masyarakat mengonsumsi beragam bentuk media massa antara lain televisi, koran, majalah, radio, dan internet. Studi Nielsen tahun 2018 menunjukkan bahwa konsumen menghabiskan waktu untuk menonton TV sebanyak rata-rata 4 jam 53 menit per hari, sedangkan mengakses internet rata-rata 3 jam 14 menit per hari, diikuti dengan mendengarkan radio sebanyak 2 jam 11 menit, membaca koran 31 menit dan membaca majalah sebanyak 24 menit (Nielsen Press Releases, 2019).

Media massa menampilkan berbagai jenis tayangan mulai berita hingga hiburan. Hal tersebut sesuai dengan fungsi komunikasi massa seperti yang dipaparkan oleh John Vivian dengan bukunya The Media of Mass Communication (1991) dalam (Nurudin, 2017, p.64) yaitu providing information, providing entertainment, helping to persuade, dan contributing to social cohesion. Dari berbagai fungsi tersebut, penyediaan informasi merupakan yang utama. "Fungsi informasi merupakan fungsi paling penting yang terdapat dalam komunikasi massa (Nurudin, 2017 , p.66). Fungsi informasi tersebut tidak hanya dilakukan oleh pemberitaan, tetapi juga iklan. Iklan, dalam beberapa hal juga memiliki fungsi memberikan informasi di samping fungsi-fungsi lain (Nurudin, 2017).

Salah satu topik yang pernah ramai di media massa adalah pemberitaan mengenai susu kental manis. Berita tentang produk ini banyak muncul di berbagai media massa, antara lain dipicu oleh keluarnya Surat Edaran Badan Pengawas Obat dan Makanan (BPOM) nomor HK.06.5.51.511.05.18.2000 tentang Label dan Iklan pada Produk Susu Kental dan Analognya (Kategori Pangan 01.3) pada 30 Mei 2018 (Badan Pengawas Obat dan Makanan, 2018). Surat itu menyebutkan, bahwa untuk melindungi konsumen terutama anak-anak dari informasi yang tidak benar dan menyesatkan, perlu diambil langkah perlindungan yang memadai.

BPOM menggelar jumpa pers pada 9 Juli 2018 terkait surat edaran tersebut. Kepala BPOM Penny Lukito dalam konferensi pers tersebut mengatakan, BPOM telah menemukan pelanggaran dalam tayangan iklan sejumlah produk susu kental manis. Kepala BPOM menyebut, ada beberapa visualisasi dalam iklan produk susu kental manis yang melanggar ketentuan. Misalnya, ada iklan yang memunculkan gambar anak berusia di bawah lima tahun atau gambar yang menyamakan susu kental manis dengan susu biasa. Menurut Kepala BPOM, hal itu akan memberikan persepsi yang salah dan dapat mendorong anak-anak mengonsumsi produk susu kental manis secara berlebihan (Ramadhan, 2018).

Di lain sisi, susu merupakan produk populer di masyarakat dengan kandungan berbagai zat gizi penting yang dibutuhkan manusia. Susu juga termasuk dalam daftar barang kebutuhan pokok yang diperlukan masyarakat di samping barang kebutuhan pokok lain sesuai Keputusan Menteri Perindustrian dan Perdagangan Nomor 115 tahun 1998 tentang Jenis Barang Kebutuhan Pokok Masyarakat (Kementerian Perindustrian, n.d.).

Susu kental manis merupakan produk yang familiar di tengah masyarakat di Indonesia. Menurut Basis Data Konsumsi Pangan Kementerian Pertanian RI, susu kental manis memiliki tingkat konsumsi tertinggi di antara jenis susu lainnya. Meski angka konsumsi fluktuatif tahun per tahun, namun trendnya cenderung meningkat. Pada 2017, tingkat konsumsi susu kental manis adalah 1,842 liter per kapita per tahun (Kementerian Pertanian, 2018).

Siaran pers Kementerian Perindustrian pada 6 Juli 2018 menyatakan produk ini mulai masuk ke Indonesia pada 1873. Kala itu Nestle mendatangkan susu kental manis merek Milkmaid yang kemudian dikenal dengan nama Cap Nona. Pada tahun 1922 De Cooperatve 
Condensfabriek Friesland yang sekarang bernama PT Frisian Flag melakukan hal yang sama dengan produk Friesche Vlag. Dua puluh dua tahun setelah Indonesia merdeka, pada akhir 1967, Indonesia mulai memproduksi susu kental manis sendiri melalui PT Australian Indonesian Milk yang kini dikenal sebagai PT Indolakto. PT Frisian Flag kemudian mengikuti jejak PT Australian Indonesian Milk pada 1971 dengan pabrik di Pasar Rebo, Jakarta Timur. Pada 1973, PT Nestle Indonesia melakukan hal serupa dengan pabrik di Jawa Timur. Industri susu kental manis terus berkembang hingga kini, dengan kapasitas produksi pabrik di dalam negeri mencapai 812 ribu ton per tahun. Sedangkan nilai investasi di sektor usaha ini mencapai angka Rp 5,4 triliun dengan total penyerapan tenaga kerja sebanyak 6.652 orang (Kementerian Perindustrian, 2018).

Selama puluhan tahun masyarakat Indonesia nyaman mengonsumsi produk susu kental manis ini. Masyarakat, bahkan ada yang mengandalkan susu kental manis sebagai sumber makanan bagi bayi. Kasus yang menarik perhatian adalah 4 balita gizi buruk di Kendari, Sulawesi Tenggara dan Maros, Sulawesi Selatan, hasil penelusuran Yayasan Peduli Negeri (YPN) dan Yayasan Abhipraya Insan Cendekia Indonesia (YAICl). Dikutip dari Indopos, kasus gizi buruk tersebut disebabkan konsumsi susu kental manis sebagai pengganti Air Susu Ibu (ASI). Para balita ini mulai mengonsumsi susu kental manis bahkan sejak berusia 4 bulan. Orang tua balita ini mengaku tidak mengetahui jika susu kental manis tidak boleh diberikan kepada bayi. Di berbagai daerah juga ditemukan adanya masyarakat yang memberikan susu kental manis sejak anak mereka masih usia dini (Indopos, 2018).

Oleh karena itu, pemberitaan di berbagai media massa tentang susu kental manis menimbulkan berbagai reaksi di masyarakat. Pemberitaan tentang susu kental manis di media massa menimbulkan efek tertentu pada tiap audiens. Baran \& Davis (2014, p.310) mengatakan "penelitian efek telah lama dikelompokkan apakah hal tersebut melibatkan satu dari tiga jenis efek yang besar yaitu kognitif, afektif, dan perilaku".

Cangara (2008) mengatakan bahwa "pada tingkat pengetahuan, efek bisa terjadi dalam bentuk perubahan persepsi dan perubahan pendapat". Media massa lebih banyak memiliki efek pada aspek pengetahuan. la mengatakan, "dari berbagai studi yang dilakukan terhadap efek atau pengaruh dalam komunikasi massa, ditemukan bahwa komunikasi massa cenderung lebih banyak mempengaruhi pengetahuan dan tingkat kesadaran seseorang" (Cangara, 2008).

Beberapa penelitian telah dilakukan untuk mengetahui efek dari pemberitaan media massa terhadap persepsi masyarakat. Fajar \& Restivia (2011) meneliti mengenai Pengaruh Pemberitaan Surat Kabar Kompas, Seputar Indonesia dan Media Indonesia terhadap Persepsi Masyarakat Pengguna Tabung Gas. Berbagai pemberitaan di media mengenai ledakan tabung gas dapat menimbulkan persepsi tersendiri pada masyarakat. Hasil penelitian ini menyebutkan bahwa pemberitaan surat kabat Kompas, Seputar Indonesia, dan Media Indonesia berpengaruh positif dan signifikan terhadap persepsi ibu rumah tangga pengguna tabung gas (Fajar \& Restivia, 2011).

Penelitian lain untuk mengetahui efek pemberitaan adalah yang dilakukan oleh Elton (2007) dengan judul Pengaruh Pemberitaan Surat Kabar terhadap Persepsi Masyarakat Pengguna Jasa Transportasi Udara di Surabaya (Kasus Studi Kecelakaan Pesawat Adam Air). Peneliti mencoba mengungkap apakah pemberitaan kecelakaan pesawat terbang akan berpengaruh pada persepsi masyarakat pengguna transportasi udara. Hasil peneltian Elton menyatakan bahwa tidak ada pengaruh yang signifikan antara variabel berita surat kabar mengenai kasus kecelakaan pesawat Adam Air terhadap persepsi masyarakat pengguna jasa transportasi udara di Surabaya (Elton, 2007).

Studi mengenai efek pemberitaan juga dilakukan untuk bidang politik. Zulkarnain (2016) melakukan penelitian berjudul Pengaruh Terpaan Berita Vonis Mantan Presiden PKS Terhadap Pilihan pada Pemilu Legislatif 2014. Penelitian tersebut dilakukan terhadap anggota atau kader PKS. Studi yang dilakukan Zulkarnain memiliki kesimpulan bahwa terpaan berita vonis mantan presiden PKS berpengaruh positif dan signifikan terhadap pilihan dari kader/anggota PKS Kelurahan Grogol Kecamatan Limo Depok.

Media menjadi salah satu sumber informasi yang bisa mempengaruhi pandangan dan persepsi masyarakat. Oleh karena itu, studi mengenai efek media pada masyarakat menjadi hal 
yang menarik. Pemberitaan mengenai susu kental manis yang marak di media massa menimbulkan pertanyaan apakah akan berpengaruh terhadap persepsi masyarakat. Penelitian terdahulu dan berbagai teori komunikasi menjadi acuan dalam dalam penelitian ini. Hingga beberapa tahun berselang sejak keluar surat edaran BPOM, pemberitaan mengenai susu kental manis sendiri hingga tahun 2020 masih menarik perhatian beberapa media terkait dengan kandungan gizinya.

Pemberitaan tentang susu kental manis yang muncul di berbagai media pada tahuntahun belakangan ini dapat menimbulkan efek tertentu pada tiap audiens. Hal ini mengacu sebagaimana yang dikatakan Nurudin bahwa "kebanyakan orang menetapkan apa yang baik dan tidak baik itu berdasarkan informasi dari media massa" (Nurudin, 2017, p.2).

Persepsi yang terbentuk menjadi penting untuk diketahui karena akan berhubungan dengan bagaimana individu maupun anggota keluarga memenuhi kebutuhan konsumsi terutama jika dikaitkan dengan upaya peningkatan kebutuhan zat gizi. Oleh karena itu, permasalahan yang ingin diangkat dalam penelitian ini adalah bagaimana pengaruh pemberitaan media massa terhadap persepsi ibu tentang susu kental manis?

\section{METODE PENELITIAN}

Penelitian ini menggunakan pendekatan kuantitatif dengan metode survey eksplanatif. Jenis survey ini, "bermaksud untuk menjelaskan hubungan (korelasi) antar variabel" (Kriyantono, 2014, p.60). Dalam hal ini, penelitian dilakukan dengan menggunakan kuisioner berisi sejumlah pertanyaan-pertanyaan kepada responden untuk mengetahui pengaruh pemberitaan media massa terhadap persepsi responden tentang susu kental manis.

Pada penelitian ini, populasi yang diteliti adalah para ibu dari siswa Taman Kanak-kanak Islam Terpadu (TKIT), Taman Pendidikan Al-Quran (TPQ), dan Sekolah Dasar Islam Terpadu (SDIT) kelas 1 yang berada dalam naungan Yayasan Masjid Al-Hikmah, Tangerang Selatan. Kalangan siswa TKIT, TPQ, dan SDIT Al-Hikmah ini dipilih dengan alasan bahwa mereka termasuk golongan usia yang memerlukan asupan gizi yang adekuat untuk tumbuh kembang optimal, yang direkomendasikan untuk mengonsumsi susu. Peraturan Menteri Kesehatan Republik Indonesia Nomor 41 Tahun 2014 tentang Pedoman Gizi Seimbang menyatakan bahwa susu sebagai bagian dari pangan hewani yang dikonsumsi berupa minuman dianjurkan terutama bagi ibu hamil, ibu menyusui, serta anak-anak setelah usia satu tahun (Kementerian Kesehatan Republik Indonesia, 2014).

Alasan ibu siswa dipilih karena mereka memiliki peran sebagai penyedia konsumsi sekaligus pengatur sumber daya rumah tangga. Engel \& Blackwell (1995) membuat matriks untuk mengklasifikasikan pengaruh suami dan istri dalam menentukan keputusan pembelian di rumah tangga. Beberapa produk atau jasa, keputusan pembelian didominasi oleh istri atau ibu rumah tangga, yaitu pakaian wanita, pakaian anak-anak, dan bahan makanan. Sedangkan yang termasuk dalam dominasi pria atau bapak rumah tangga antara lain pakaian pria, peralatan olahraga, atau permainan (games). Susu merupakan salah satu bahan makanan untuk konsumsi. Dalam keluarga, konsumsi makanan sangat ditentukan oleh ibu dengan perannya sebagai gate keeper yang bertanggung jawab dalam pemilihan hidangan keluarga. Dengan perannya ini, ibu rumah tangga akan memikirkan konsumsi untuk keluarga, kemudian mengumpulkan informasi, dan pada akhirnya mengambil keputusan. Populasi ini diketahui juga tidak mengalami kesulitan untuk mengakses berbagai pemberitaan media massa.

Jumlah populasi dalam penelitian ini adalah sebanyak 162 orang tua, dengan sampel berjumlah 116, yang dihitung berdasarkan rumus Slovin.

Penelitian ini mengandung variabel bebas (independent) dan variabel terikat (dependent). Variabel independen (X) adalah pemberitaan media massa, sedangkan variabel dependen $(Y)$ adalah persepsi ibu tentang susu kental manis.

Variabel independen (X) untuk pemberitaan surat kabar merupakan sesuatu yang ditampilkan di media massa mengenai susu kental manis dengan merujuk pada dimensi nilai berita. Siregar (1998) mengatakan ada ukuran-ukuran tertentu yang harus dipenuhi agar suatu kejadian atau suatu peristiwa dalam masyarakat dapat diberitakan pers, yang disebut news 
value. Nilai berita atau news value dalam media massa terdiri dari beberapa elemen, antara lain Significance (penting), Magnitude (besar), Timeliness (waktu), dan Proximity (kedekatan). Oleh karena itu, variabel independen $(X)$ diukur berdasarkan empat elemen tersebut.

Sedangkan variabel dependen $(\mathrm{Y})$ adalah persepsi yang terdiri dari beberapa indicator yaitu Selective Exposure, Selective Attention, Perceptual Defense, Perceptual Blocking, Perceptual Organization, dan Perceptual Interpretation. Hal itu berdasarkan apa yang dipaparkan oleh Leon G. Schiffman dan Leslie Lazar Kanuk dalam buku Consumer Behavior yaitu, "consumer's selection of stimuli from the environment is based on the interaction of expectations and motives with the stimulus itself" (Schiffman \& Kanuk, 2007:158).

Penelitian ini menggunakan analisis regresi linier sederhana. Persamaan umum regresi linear sederhana adalah sebagai berikut (Sugiyono, 2019):

$$
Y=a+b X
$$

$\mathrm{Y}=$ Subyek dalam variabel dependen yang diprediksikan

$a=$ Harga $Y$ ketika harga $X=0$ (harga konstan)

$\mathrm{b}=$ Angka arah atau koefisien regresi

$\mathrm{X}=$ Subyek pada variabel independen

Pengujian hipotesis menggunakan uji t. Jika $\mathrm{t}$ hitung lebih besar dari $\mathrm{t}$ tabel maka terdapat hubungan yang signifikan. Pengujian hipotesis juga melihat nilai signifikansi atau $p-$ value, yaitu jika nilai signifikansi $<0,05$ maka terdapat pengaruh variabel indenden terhadap variabel dependen.

\section{HASIL PENELITIAN DAN PEMBAHASAN}

Beberapa tahun terakhir pemberitaan susu kental manis banyak dimuat di media massa. Penulis menelusuri artikel-artikel mengenai produk ini melalui Google pada Februari 2020 di berbagai media online untuk menghitung jumlah pemberitaan di media massa dengan menggunakan kata kunci "susu kental manis".

Beberapa media online yang telah terdaftar dalam Dewan Pers dimasukkan dalam pencarian ini, antara lain Kompas (kompas.com), Tempo (tempo.co), Detik (detik.com), Kumparan (kumparan.com), Republika (republika.co.id), Liputan 6 (liputan6.com), dan Tirto (tirto.id). Periode penerbitan artikel terbagi dalam tiga periode yaitu tahun 2017, 2018, dan 2019.

Dari tabel terlihat bahwa di berbagai media terjadi lonjakan jumlah pemberitaan mengenai susu kental manis pada 2018. Pemberitaan mengenai susu kental manis di kompas.com mengalamai kenaikan sebesar 134 persen, tempo.co (267 persen), detik.com (37 persen), republika.co.id (112 persen), kumparan.com (650 persen), liputan6.com (474 persen), dan tirto.id (200 persen).

Tabel 1. Jumlah Pemberitaan Susu Kental Manis di Media Massa

\begin{tabular}{lrrrr}
\hline \multirow{2}{*}{ Media } & \multicolumn{3}{c}{ Tahun } & \multirow{2}{*}{ Total } \\
\cline { 2 - 4 } & 2017 & 2018 & 2019 & 177 \\
\hline Kompas.com & 41 & 96 & 40 & 169 \\
Tempo.co & 21 & 77 & 71 & 541 \\
Detik.com & 139 & 191 & 211 & 83 \\
Republika.co.id & 17 & 36 & 30 & 112 \\
Kumparan.com & 8 & 60 & 44 & 395 \\
Liputan6.com & 35 & 201 & 159 & 41 \\
Tirto.id & 4 & 12 & 25 & 1.518 \\
\hline \multicolumn{1}{c}{ Total } & 265 & 673 & 580 & \\
\hline
\end{tabular}

Sumber : Mesin Pencari Google 
Meski tahun 2018 telah terlewati, pemberitaan susu kental manis tidak juga usai pada 2019. Meski sedikit berkurang dibanding 2018, namun jumlah pemberitaan tersebut tetap jauh lebih banyak dibanding tahun 2017. Kompas.com bahkan mencatat, bahwa susu kental manis menjadi trending topic di media sosial twitter justru pada akhir 2019 (Arnani, 2019).

\section{Skor Tanggapan Responden}

Untuk variabel pemberitaan media massa, tanggapan responden yang diukur berdasarkan dimensi pemberitaan magnitude, timeliness, significance, dan proximity menghasilkan skor sebesar 3.626. Penilaian tanggapan responden untuk variabel persepsi yang diukur berdasarkan dimensi selective exposure, selective attention, perceptual defense, perceptual blocking, perceptual organization, dan perceptual interpretation menghasilkan skor sebesar 6.820 .

Untuk menetapkan kriteria penilaian terhadap jawaban responden apakah termasuk dalam kategori tinggi, sedang, atau rendah maka terlebih dahulu ditentukan skala interval yang diinterpretasikan dengan alat bantu tabel kontinu, sebagai berikut :

NJI (Nilai jenjang interval) $=\frac{\text { Nilai tertinggi-Nilai terendah }}{\text { Jumlah kriteria pertanyaan }}$

Tabel 2. Kriteria Penilaian Tanggapan terhadap Variabel Pemberitaan Media Massa

\begin{tabular}{l|l}
\hline \multicolumn{1}{c|}{ Interval } & \multicolumn{1}{c}{ Kategori } \\
\hline $1.160-2.030$ & Sangat Rendah \\
\hline $2.031-2.900$ & Rendah \\
\hline $2.901-3.770$ & Tinggi \\
\hline $3.771-4.640$ & Sangat Tinggi \\
\hline Sumber : Data (diolah) &
\end{tabular}

Tabel 3. Kriteria Penilaian Tanggapan terhadap Variabel Persepsi

\begin{tabular}{l|l}
\hline \multicolumn{1}{c|}{ Interval } & \multicolumn{1}{c}{ Kategori } \\
\hline $2.088-3.654$ & Sangat Rendah \\
\hline $3.655-5.220$ & Rendah \\
\hline $5.221-6.786$ & Tinggi \\
\hline $6.787-8.352$ & Sangat Tinggi \\
\hline
\end{tabular}

Sumber : Data (diolah)

Hasilnya, total skor 3.626 untuk variabel pemberitaan dalam kriteria penilaian tanggapan berada pada kategori tinggi. Sedangkan total skor 6.820 untuk variabel persepsi berada pada kategori penilaian sangat tinggi.

\section{Analisis Regresi Linear Sederhana}

Berdasarkan hasil pengolahan dengan perangkat lunak Statistical Product and Service Solution (SPSS) diperoleh persamaan regresi linear sederhana sebagai berikut :

$$
Y=24,963+1,082 X
$$

Nilai konstanta persamaan regresi di atas adalah sebesar 24,963. Artinya, jika variabel Persepsi $(Y)$ tidak dipengaruhi oleh variabel independennya yaitu Pemberitaan Media $(X)$, maka akan bernilai 24,963. Koefisien regresi untuk variabel independen Pemberitaan Media (X) bernilai positif, menunjukkan adanya hubungan yang searah antara Pemberitaan Media $(X)$ dengan Persepsi ( $Y$ ). Koefisien regresi variabel Pemberitaan Media (X) sebesar 1,082 mengandung arti untuk setiap pertambahan Pemberitaan Media (X) sebesar satu satuan akan menyebabkan meningkatnya Persepsi $(\mathrm{Y})$ sebesar 1,082. 


\section{Uji Hipotesis}

Uji Hipotesis dilakukan untuk menunjukkan apakah terdapat pengaruh variabel independen yang signifikan terhadap variabel dependen.

$\mathrm{Ho}=$ Tidak terdapat pengaruh Pemberitaan Media Massa $(X)$ terhadap Persepsi Para Ibu Siswa Sekolah Al-Hikmah tentang Susu Kental Manis ( $Y$ )

$\mathrm{Ha}=$ Terdapat pengaruh Pemberitaan Media Massa $(X)$ terhadap Persepsi Para Ibu Siswa Sekolah Al-Hikmah tentang Susu Kental Manis $(Y)$

Pengambilan keputusan berdasarkan nilai $t$ hitung dan $t$ table. Jika $t$ hitung lebih besar dari $t$ table maka Ho ditolak. Sebaliknya jika $t$ hitung lebih kecil dari $t$ table, maka Ha ditolak dengan tingkat signifikan yang digunakan yaitu 0,05 .

Hasil perhitungan memperoleh nilai t hitung adalah 8,375. Angka ini lebih besar dari nilai t table yaitu 1,98099. Nilai signifikansi ( $p$-value) juga lebih kecil dari 0,05 . Oleh karena itu, Ho ditolak. Dengan demikian disimpulkan bahwa pemberitaan media massa memiliki pengaruh signifikan terhadap persepsi para ibu siswa sekolah Al-Hikmah tentang susu kental manis.

\section{Pembahasan}

Tanggapan responden atas pertanyaan penelitian menghasilkan skor sebesar 3.626, yang menunjukkan bahwa pemberitaan susu kental manis memiliki nilai berita yang cukup tinggi bagi responden. Pemberitaan mengenai susu kental manis tersebut mendapatkan skor tanggapan yang berada pada kategori tinggi untuk empat nilai berita yang diukur, yaitu magnitude sebesar 3,13 , timeliness sebesar 3,11 , significance sebesar 3,03 dan proximity sebesar 3,19. Siregar (1998) yang membuat bagan urutan nilai berita yaitu significance, timeliness, magnitude, proximity menyatakan semakin banyak unsur informasi mendekati unsur signifikan, maka informasi semakin penting bagi pembaca. Jika semakin banyak unsur informasi mendekati unsur proximity, maka menurut Siregar, semakin menarik berita tersebut. Pemberitaan mengenai susu kental manis mendapatkan skor tanggapan yang berada pada kategori tinggi untuk semua nilai berita yang diukur. Unsur proximity atau kedekatan berada di urutan teratas sehingga dapat dikatakan unsur ketertarikan audiens sangat besar untuk pemberitaan ini.

Sebagian besar responden mengaku mengakses pemberitaan di media massa melalui internet (75,9 persen) dan melalui televisi sebesar 23,3 persen. Hanya satu responden yang menyatakan mengakses sebagian besar pemberitaan dari media cetak. Responden juga mengakses pemberitaan tidak hanya dari satu media, melainkan dari berbagai sumber, berkat penggunaan gawai pintar dan internet. Perkembangan teknologi semakin memperluas komunikasi yang memberikan kenyamanan dan kemudahan dalam mengakses informasi tanpa batasan jarak dan waktu.

Responden memenuhi berbagai kebutuhan terkait informasi dari media, yang memiliki fungsi antara lain untuk memberi informasi, mendidik, mempersuasi, dan memuaskan kebutuhan audiens, sebagaimana yang digambarkan oleh Teori Sistem Ketergantungan Media. Teori ini menyatakan bahwa dalam masyarakat industri, "kita menjadi semakin bergantung pada media untuk memahami dunia sosial, untuk bertindak benar dan efektif di dalam masyarakat, serta untuk fantasi dan pelarian" (Baran \& Davis, 2014, p.340). Teori Ketergantungan Sistem Media juga berasumsi bahwa semakin seseorang menggantungkan kebutuhannya untuk dipenuhi oleh penggunaan media, semakin penting peran media dalam hidup orang tersebut sehingga media akan semakin memiliki pengaruh kepada orang tersebut (Baran \& Davis, 2014, p.340). Penelitian ini mendapatkan hasil bahwa pemberitaan mengenai susu kental manis memiliki pengaruh yang signifikan terhadap persepsi responden yang mengonfirmasi apa yang dinyatakan dalam teori ketergantungan media.

Pada saat khalayak mengakses media, ia akan terekspos pada puluhan bahkan ratusan informasi. Dari berbagai paparan informasi tersebut, orang akan menyaring informasi mana yang akan masuk dalam pikiran atau informasi mana yang ia abaikan. Jika seseorang 
menganggap sebuah informasi terkait atau penting bagi dirinya, maka informasi tersebut akan memiliki peluang untuk ia perhatikan, ia olah, bahkan ia simpan. Dari beragam informasi yang ditawarkan oleh media massa, responden hampir seluruhnya memberikan tanggapan yang menyetujui bahwa informasi mengenai susu kental manis perlu mendapat perhatian dan tertarik untuk menyimak pemberitaan tersebut. Meski pemberitaan susu kental manis sudah berlalu, responden masih mengingat informasi pemberitaan dan memiliki persepsi tentang produk tersebut. Variabel persepsi sebagai efek dari pemberitaan susu kental manis memperoleh tanggapan yang tergolong dalam kategori sangat tinggi dengan total skor 6.820 .

Persepsi yang ada di benak responden merupakan hasil pengelolaan informasi yang masuk dalam pemikiran responden. Salah satu efek kognitif berupa persepsi mengenai susu kental manis dari berbagai pemberitaan di media dapat dijelaskan dengan Teori Pengolahan Informasi. "Teori Pengolahan Informasi menggunakan analogi mekanis untuk menggambarkan dan menafsirkan bagaimana masing-masing individu mengambil dan memaknai banjir informasi yang diterima indera masing-masing setiap saat setiap hari” (Baran \& Davis, 2014, p.311). Manusia memiliki sumber daya kognitif yang terbatas, oleh karena itu hanya sebagian dari informasi tersebut yang menarik perhatian dan pada akhirnya diproses dalam memori jangka panjang.

Dari berbagai sumber pemberitaan mengenai susu kental manis, responden memiliki kesimpulan tersendiri mengenai inti penting pemberitaan. Mayoritas responden (78,4 persen) menjawab poin dari berbagai pemberitaan tersebut adalah kandungan gula dalam susu kental manis. Model komunikasi Westley-Mac Lean sedikit dapat menjelaskan sehingga poin pemberitaan yang diingat oleh responden adalah mengenai kandungan gula. Dalam membuat berita, reporter tidak hanya mendapatkan berita dari satu nara sumber, melainkan juga dari berbagai sumber informasi seperti pengamatan, riset, dan nara sumber lain. Berita tersebut juga akan terlebih dahulu melewati editor sebagai gatekeeper di media bersangkutan. Soal kandungan gula pun menjadi topic atau kata kunci pada pemberitaan tentang susu kental manis. Dan hal inilah yang ditangkap responden.

Tabel 4. Poin Pemberitaan Susu Kental Manis Menurut Responden

\begin{tabular}{l|r|r}
\hline Inti Pemberitaan & $\begin{array}{l}\text { Jumlah } \\
\text { Responden }\end{array}$ & Persentase \\
\hline $\begin{array}{l}\text { Informasi produk pada label yang kurang } \\
\text { lengkap }\end{array}$ & 6 & 5,2 \\
\hline $\begin{array}{l}\text { Kandungan gula dalam produk susu } \\
\text { kental manis }\end{array}$ & 91 & 78,4 \\
\hline $\begin{array}{l}\text { Konsumsi oleh masyarakat yang kurang } \\
\text { tepat }\end{array}$ & 12 & 10,3 \\
\hline $\begin{array}{l}\text { Visualisasi iklan yang Tidak Sesuai } \\
\text { Produk }\end{array}$ & 7 & 6,0 \\
\hline
\end{tabular}

Pemberitaan di media massa juga mempengaruhi persepsi secara positif yaitu dengan mengonsumsi susu kental manis seperti yang disarankan. Responden sebagian besar juga mengonsumsi susu kental manis dengan cara dicampur ke dalam makanan dan minuman atau sebagai topping. Di sini responden mengonsumsi susu kental manis sesuai dengan yang dianjurkan seperti yang muncul dalam beberapa pemberitaan.

Namun, sebesar 33,3 persen responden mengaku mereka juga masih tetap mengonsumsi dengan cara diseduh dengan air, meski juga telah menggunakan susu kental manis sebagai campuran. Tapi pemberitaan media membuat responden kini lebih memperhatikan kandungan gizi yang tertera pada label produk. Seorang responden bahkan berulang kali mengoreksi penulis agar tidak mengatakan "susu kental manis". Menurutnya, "Itu bukan susu, jadi jangan disebut susu". 
Berdasarkan temuan ini dapat disimpulkan bahwa dalam benak konsumen, akumulasi berbagai informasi dalam rentang waktu sekitar satu tahun saja dapat memicu terjadinya proses disonansi kognitif. Karena pemberitaan media massa bisa jadi bukan satu-satunya sumber informasi, maka sangat besar sekali kemungkinan responden mendapatkan konfirmasi informasi dari sumber lainnya sehingga terdapat banyak kesenjangan antara pengetahuan, sikap, maupun perilaku.

Hasil perhitungan dengan perangkat lunak SPSS menyatakan bahwa pemberitaan media massa memberikan pengaruh sebesar 38,1 persen terhadap persepsi. Sisanya yaitu sebesar 61,9 persen merupakan kontribusi variabel lain. Penulis mencoba mencari tahu faktor apa yang mungkin berkontribusi dalam persepsi ini. Seorang responden mengaku, selain mendapatkan informasi dari pemberitaan media massa, ia juga mendapatkan informasi tentang susu kental manis dari dokter yang berpesan kepadanya agar berhati-hati dalam memberikan susu kental manis terhadap anak.

Penelitian ini berusaha menelaah efek pemberitaan susu kental manis tanpa menentukan pemberitaan media tertentu. Peneliti mengasumsikan bahwa audiens telah terlebih dahulu mengonsumsi berbagai jenis media sebelumnya dan memperoleh informasi mengenai susu kental manis. Jadi terdapat jeda waktu ketika pemberitaan mencapai puncaknya pada 2018 dengan saat penyebaran kuisioner dilakukan yaitu pada akhir 2019 hingga Februari 2020. Oleh karena itu, penelitian tidak mengidentifikasi jenis media, berita, dan intensitas paparan saat susu kental manis sedang ramai muncul di media. Studi terbatas untuk menggali apa yang ada di benak responden yang merupakan persepsi hasil dari berbagai ingatan atau informasi akumulatif yang diterima responden sebelum pengisian kuisioner.

\section{SIMPULAN}

Hasil analisis dalam penelitian ini menunjukkan bahwa pemberitaan media massa berpengaruh positif dan siginifikan terhadap persepsi para ibu siswa sekolah Yayasan AlHikmah mengenai susu kental manis. Hubungan antara pemberitaan media massa dan persepsi ibu tentang susu kental manis juga dinyatakan sebagai hubungan yang kuat.

Perhitungan nilai koefisien determinasi atau $R^{2}$ menghasilkan angka sebesar 0,381 . Artinya pemberitaan media massa memberikan pengaruh sebesar 38,1 persen terhadap persepsi. Sedangkan sisanya yaitu sebesar 61,9 persen merupakan kontribusi variabel lain selain pemberitaan media massa.

Hasil penelitian membuktikan bahwa pemberitaan mengenai susu kental manis memiliki pengaruh signifikan terhadap persepsi populasi pada penelitian ini. Ke depannya, bisa dilakukan penelitian serupa untuk mengetahui efek pemberitaan media massa mengenai susu kental manis pada populasi di daerah lain di Indonesia, yang mungkin tidak semua masyarakatnya berinteraksi secara intens dengan media massa.

Penelitian ini telah menggambarkan efek pemberitaan dan indikasi terjadinya proses disonansi kognitif konsumen, sehingga selanjutnya dapat dilakukan kajian yang dapat merumuskan strategi komunikasi terbaik bagi pihak berwenang untuk mengampanyekan aturan-aturan konsumsi produk pangan, terutama untuk produk yang banyak dikonsumsi masyarakat seperti susu kental manis. Dengan demikian kesenjangan antara harapan penerimaan informasi dengan sikap dan perilaku dapat dipersempit sehingga hasilnya lebih menunjukkan konsistensi.

Keterbatasan penelitian ini, yang cakupannya adalah pada akumulasi persepsi audiens, dapat menjadi langkah awal untuk dilakukannya penelitian selanjutnya baik dengan menggunakan pendekatan kualitatif untuk mengetahui persepsi perempuan atau ibu lebih mendalam, maupun pendekatan kuantitatif yang menambahkan variabel lain selain pemberitaan media massa yang diduga berpengaruh terhadap persepsi masyarakat.

\section{DAFTAR PUSTAKA}


Arnani, M. (2019). Trending di Twitter, Apa Bahaya Susu Kental Manis? www.kompas.com. https://www.kompas.com/tren/read/2019/11/05/200000065/trending-di-twitter-apa-bahayasusu-kental-manis?

Badan Pengawas Obat dan Makanan. (2018). Surat Edaran tentang Label dan Iklan pada Produk Susu Kental dan Analognya (Kategori Pangan 01.3). www.pom.go.id. https://www.pom.go.id/new/admin/dat/20180530/SE_SKM.pdf

Baran, S. J., \& Davis, D. K. (2014). Teori Komunikasi Massa - Dasar, Pergolakan, dan Masa Depan (A. Daud (ed.)). Salemba Humanika.

Cangara, H. (2008). Pengantar IImu Komunikasi. Rajagrafindo Persada.

Elton, L. (2007). Pengaruh Pemberitaan Surat Kabar terhadap Persepsi Masyarakat Pengguna Jasa Transportasi Udara di Surabaya (Kasus Studi Kecelakaan Pesawat Adam Air). Scriptura, 1(2), 98-110. http://puslit2.petra.ac.id/ejournal/index.php/iko/article/view/16686

Engel, J. F., \& Blackwell, R. D. (1995). Consumer Behavior (8th ed.). The Dryden Press.

Fajar, A., \& Restivia, D. Y. (2011). Pengaruh Pemberitaan Surat Kabar Kompas, Seputar Indonesia dan Media Indonesia Terhadap Persepsi Masyarakat Pengguna Tabung Gas. Jurnal ASPIKOM, 1(2), 171. https://doi.org/10.24329/aspikom.v1i2.16

Indopos. (2018). Prokontra Konsumsi SKM pada Bayi. Www.Indopos.Co.Id. https://indopos.co.id/read/2018/06/21/141730/prokontra-konsumsi-skm-pada-bayi/

Kementerian Kesehatan Republik Indonesia. (2014). Peraturan Menteri Kesehatan tentang Pedoman Gizi Seimbang. https://peraturan.bpk.go.id/Home/Details/119080/permenkes-no41-tahun-2014

Kementerian Perindustrian. (n.d.). Jenis Barang Kebutuhan Pokok Masyarakat. www.kemenperin.go.id. http://jdih.kemenperin.go.id/site/baca_peraturan/513 . (2018). Susu Kental Manis Aman Dikonsumsi, Industrinya Berkontribusi Bagi Ekonomi. Www.kemenperin.go.id. https://www.kemenperin.go.id/artikel/19413/SusuKental-Manis-Aman-Dikonsumsi,-Industrinya-Berkontribusi-Bagi-Ekonomi

Kementerian Pertanian. (2018). Basisdata Konsumsi Pangan. Www.Pertanian.Go.Id. https://aplikasi2.pertanian.go.id/konsumsi/tampil_susenas_kom2_th.php

Kriyantono, R. (2014). Teknik Praktis Riset Komunikasi. Kencana Prenadamedia.

Littlejohn, S. W., \& Foss, K. A. (2009). Teori Komunikasi (Yusuf (ed.)). Salemba Humanika.

Nielsen Press Releases. (2019). Optimizing Communication and Marketing Strategy with Nielsen Total Audience. Www.Nielsen.Com. https://www.nielsen.com/id/en/pressreleases/2019/optimizing-communication-and-marketing-strategy-with-nielsen-totalaudience/

Nurudin. (2017). Pengantar Komunikasi Massa. Rajagrafindo Persada.

Ramadhan, A. (2018). Polemik Susu Kental Manis yang Dijawab BPOM. www.kompas.com. https://megapolitan.kompas.com/read/2018/07/10/09242261/polemik-susu-kental-manisyang-dijawab-bpom?page=all

Rivers, W. L., Peterson, T., \& Jensen, J. W. (2008). Media Massa dan Masyarakat Modern (H. Munandar \& D. Priyatna (eds.); Terjemahan). Kencana Prenadamedia.

Schiffman, L. G., \& Kanuk, L. L. (2007). Consumer Behavior. Pearson Education.

Siregar, A. (1998). Bagaimana Meliput dan Menulis Berita untuk Media Massa. Kanisius.

Sugiyono. (2019). Statistika untuk Penelitian. Alfabeta.

Zulkarnain. (2016). Pengaruh Terpaan Berita Vonis Mantan Presiden Partai Keadilan Sejahtera (PKS) terhadap Pilihan dalam Pemilihan Umum Legislatif 2014. Universitas Muhammadiyah Jakarta. 